\title{
Miscellanea
}

\section{Processes of Coping with Difference among Adolescents}

\author{
NATALIE POWROZNIK \\ University of Münster \\ DILEK A. TEPELI \\ Ruhr-University Bochum \\ MARTINA LOTH \\ University of Münster
}

\begin{abstract}
Against the backdrop of their collective identity, identity formation poses a special challenge to young Alevis and Afghan Christians. In Turkey, Alevis constitute a marginalized group not officially recognized by the state. In Afghanistan, conversion to Christendom is denounced as apostasy and is punished with death. This contribution compares the coping strategies of two young adults who are radically segregated by the state's majority due to their marginalized religious identity. German diaspora offers new degrees of freedom. Thus, besides many psychosocial burdens for immigrants and their descendants, the two adolescents can confidently accept their difference and integrate it into their diverse identity.
\end{abstract}

KEYWORDS coping processes, adolescence, migration/diaspora communities, religion, identity, Alevi faith, Christian conversion, refugees

\section{Introduction: Religious Plurality and Difference}

As part of the interdisciplinary graduate school "Regulating Religious Plurality in the Region," we have dealt with religious plurality from different perspectives and, in doing so, have constantly been confronted with challenges involved in the perception of religious plurality. Our individual doctoral projects are therefore concerned above all with difference. Since society often perceives difference that is marked as religious or cultural as being especially problematic, it is vital to find a way to deal with difference. From its Latin origins, difference means, 
first of all, "diversity" or something "set apart." In everyday life, it is constructed in social processes of production and differentiation in terms of intersectional categories such as age, gender, generation, culture, and religion, and it can manifest itself through attributions (Utler 2019, 93, 96). Difference thus encompasses more than just religious and/or cultural attributions (or experiences) (Utler 2013), since action is to be understood fundamentally as being determined culturally, socially, and biographically (Utler 2019, 96). According to Astrid Utler, "[a]ny behaviour can potentially lead to experiences of difference that have the character of foreignness [...] whenever the behaviour continuously exceeds the framework of orientation of the respective groups in terms of degree, situational use, and quality" (Utler 2013, 315). ${ }^{1}$ The investigation of difference, and the experience of difference and how subjects themselves interpret it, should therefore not be reduced to culture or religion alone, even though (national) culture or, more specifically, religion is used especially in the context of migration as the "basis for constructing difference" (Utler 2013, 93, 96). Moreover, difference should be understood not only as an attribution but also as an experience (Utler 2019, 97):

While experienced foreignness is based on concrete experiences, attributed foreignness makes use of the public discourse, which constructs selected groups as foreign - experiences are only drawn on here to make the attribution plausible. (Utler 2013, 13)

We have to content ourselves at this point with these sketchy remarks on the notion of difference. Since adolescence is enormously important for dealing with perceived, attributed, and experienced differences, we will deal precisely with this dynamic and developmentally significant phase of life. Our empirical case studies focus on the attributions that adolescents give themselves and others, on how they perceive and cope with experiences of difference, and on the significance that these experiences have for their identity formation. We will first present the case of Jawid, ${ }^{2}$ a young Afghan man from an ethnic minority who has converted to Christianity, and then that of Eylül, ${ }^{3}$ a young Alevi woman from an Alevi family that is nonetheless shaped by Sunniism. Finally, we will bring the two cases together and highlight the importance of multiple belongings for research on youth religiosity.

\section{Identity and Adolescence ${ }^{4}$}

It is important in our opinion to give a clear definition of the notion of identity since, in its "enigmatic ambiguity" (Straub 2000), it is often used extremely unclearly or even problematically. Jürgen Straub argues that "the notion of personal identity" is "a formal theoretical construct." For him, the notion of identity "describes the unity of a person which is especially ensured through the coherence (of moral, aesthetic maxim systems and social roles) as well as the (narratively constituted) continuity" (Straub 2000, 167). Thus, fundamental to this understanding of identity is a subject structure within late modern society, one that must be open to alterity, plurality, and contingency. Following the psychoanalyst Erik Erikson, Straub

$1 \quad$ In the following, all quotes were translated from German by the authors.

2 The field interview with Jawid comes from Natalie Powroznik's doctoral project and was conducted in 2017.

3 The interview material is taken from the doctoral projects of Martina Loth and Dilek Tepeli, who coincidentally both conducted a narrative interview with Eylül in 2018.

$4 \quad$ Many parts of this section are taken from the joint contribution Loth and Tepeli (2019). 
claims that identity as a specifically late modern form of subjectivation includes the synthesis of the different into a coherent unity (ibid.). Straub distinguishes this understanding of identity from the notion of qualitative identity, which encompasses the self-descriptions that individuals have of themselves, their biography, emotions, needs, and experiences (Straub 2000, 281). Our empirical study is more concerned with selected aspects of the qualitative identity of our narrators and concentrates on the predicates of identity that are fundamental to them as well as on the ethical and moral beliefs and orientations embedded within them. These we establish from their self-world descriptions and from their narratives.

We should also note that questions of identity in individualized, pluralized, and detraditionalized societies are always connected with doubts and uncertainties about who a person (or, in the case of Alevis, also a group) is or wants to be. These uncertainties about one's own identity are closely intertwined with the proliferation of options for action and life plans in late modernity, since "anyone who asks about his or her identity is not (or no longer) sure of it" (Straub 2000, 280).

Erik H. Erikson demonstrated in his eight-step psychosocial model of identity formation ${ }^{5}$ that individuals must resolve a psychosocial crisis ${ }^{6}$ at every stage of identity development (see 2015). It is especially the phase of adolescence, which is deemed a particularly significant part of the life cycle, that is concerned with the mental maturation that enables young people to take on social responsibility (Erikson 2015, 91). Erikson makes clear that this period can be described as "a psychosocial moratorium, during which the human being freely experiments with roles in the search for his or her place in some sector of society, a niche that is clearly defined and yet seems to be made for him or her alone" (Erikson 2015, 137-38, our emphasis). For, in adolescence, young adults also have to deal with essential identity issues concerning their origin and future (Gärtner 2013, 214). Adolescents with a migration background undergo a double process of transformation: the transition from childhood to adulthood and the transformation associated with migration itself (King and Koller 2006, 11).

\section{Empirical Case Studies - Religion and Culture as Difference}

\section{Flight as Christian and Hazara from Afghanistan}

Young people with a refugee background must also undergo this double process of transformation, something especially difficult for 15-year-old Jawid Bakhtari, ${ }^{7}$ who comes from a family that, having converted to Christianity, suffered serious persecution in his country of origin, Afghanistan. The Bakhtari family are from a rural area in central Afghanistan and belong to the Hazara ethnic minority. Originally Shiite, the family fled to Germany because of their conversion to Christianity and the threats that accompanied it. Neither the father Rashed nor his son Jawid could read or write when they were assigned local housing in 2015. Both speak

5 The notion of identity has been the object of much criticism. Brubaker and Cooper (2000), for example, point out in their well-known essay, "Beyond 'identity," that there are manifold forms of use that run in opposite directions. They mention the following interpretations of identity: "particularistic categorical attributes (race, ethnicity, gender, sexual orientation)," "a fundamental and consequential sameness among members of a group or category," "a core aspect of ... 'selfhood' point[ing] to something allegedly deep, basic, abiding, or foundational," "both [a] contingent product of social or political action and [...] a ground or basis of further action," "the unstable, multiple, fluctuating, and fragmented nature of the contemporary 'self'" (King and Koller 2006, 6-7). They therefore reject the term as an analytical tool - unlike ourselves. Crisis means a development-related "turning point, a critical period of increased vulnerability and potential, and thus the ontogenetic source of strength or generational mismatch" (Erikson 2015, 96). All names used in the article are pseudonyms. 
Hazaragi, a local dialect, and Dari, and are gradually learning German. Both father and son make use of additional language courses and can now communicate very well in German after only a few months. Nevertheless, Jawid feels caught in a relationship of tension with regard to the everyday expectations placed on him. In the refugee centre, he bears equal responsibility with his father for the needs of daily life. He goes shopping, cooks, cleans, and manages his appointments on his own. He also discusses with his father any mail from the authorities and deals with the situation regarding a possible deportation to Afghanistan. At school, on the other hand, he often feels patronized. The teacher tells him which book he has to work with; the timetable dictates when he has to be in which classroom; and, if he wants to go to the restroom, he first has to tell the teacher so that she can give him the key. On some days, Jawid feels relief that he has to make fewer decisions, while on other days, especially when he feels agitated inside, this makes him aggressive and leads him to doubt the benefits of going to school.

But it might be mistaken to assume that this is linked directly to Jawid's background. We can assume that, when he was in Afghanistan, he also enjoyed certain privileges appropriate to his age, but that he had to follow a set of rules in other contexts as well. His subordination at school in Germany could thus also be interpreted as an act of rationalization on Jawid's part, which he uses to express his dissatisfaction with his new everyday life. As a result, he idealizes his country of origin by telling the researcher what freedoms he enjoyed in Afghanistan and that he was treated as a 'man' there. This shows that Jawid also experienced a "phase of play and learning" (Zito 2017, 238) in Afghanistan, one, however, that took on a different form than that of his German schoolmates, since it was subject to different framework conditions. And like other young people, he too asks himself questions about his life plans and relates them to his religious affiliation, which he perceives as a difference to his past identity.

Jawid describes his perspective as follows: "We're Christians now. We can't go back anymore now." His dream is "to become a policeman in Germany." He fleshes out his vision of the future by saying: "We'll have our own flat later, we'll go to church, I'll be a policeman and then my dad can be very proud of me when I'm a policeman. I'll protect my dad then." 8 The example shows that young people who have been forced to flee must ask themselves the same questions as other young people. They also make plans and have an idea of what they want to do with their lives. As for the conversion of father and son, the quote also shows that Jawid is aware of the consequences of his decisions. By saying, "We're Christians now. We can't go back anymore now," he shows that he is aware of the fact that certain decisions in life set the course for the future, and confesses to a difference that would endanger his life in his country of origin. He is aware that, as a person with the status of a refugee and as a converted Christian, he has a limited range of possibilities. This can certainly be read as a sign of autonomy in that, for example, he takes on responsibility and assumes a group affiliation that differentiates him from the majority of believers in his home country.

If the adolescent search for identity typically involves processes of separation and detachment from the milieu of origin, then adolescence under conditions of flight has its own specificity for Jawid, since his attachment to his father and the responsibility for him that goes with it do not lead to debonding but rather to a stronger attachment to his father and to his milieu of origin (shown in the desire to protect his father). But his difficult situation, due to his flight as an experience of crisis, stimulates his development and fosters his potential for growth (Erikson 2015, 144). Jawid now takes on an active role in shaping and planning 
his future, although he has a double crisis to confront: as a young man exploring his future prospects, and as the son of a father struggling with alcoholism as a psychosocial consequence of the experience of flight.

Baumann $(2017,44)$ argues that as a marker of difference, religious belonging often acquires a new visibility precisely in the context of migration (see also Krech 2008), which is particularly true of Jawid through his conversion. Pfaff-Czarnecka emphasizes that "common ground is often perceived through a shared social horizon that helps distinguish between insiders and outsiders, while at the same time being fortified by this distinction" (2012, 3:22). By belonging, Pfaff-Czarnecka therefore understands "individually acquired life knowledge and feelings whose practice unfolds in highly conflictive confrontations with the drawing of social boundaries" (2012, 3:9). However, this drawing of social boundaries cannot be studied independently of affiliations and plays a role inasmuch as Pfaff-Czarnecka describes it as a special challenge of the present day, especially in plural societies. It is precisely "in the communicative spaces of immigration societies" (Pfaff-Czarnecka 2012, 3:9) that the desire for an unambiguous location and belonging becomes clear. ${ }^{9}$ Jawid is sure of his belonging and is aware of his differences, but he does not allow them to prevent his realizing his plans. He acts independently and positions himself in the areas mentioned - full of hope for a better future.

\section{Becoming an Alevi by Choice ${ }^{10}$}

The case of Eylül is also shaped by a double process of transformation, since the adolescence of children of the second generation (which also includes Eylül) is also shaped by the consequences of migration for the family and the way that the parents cope with these consequences (King and Koller 2006, 11). At the time of the interview, Eylül is 21 years old and a member of the board of the Alevi youth group in her city in the Ruhr area, a group that belongs to the Bund der Alevitischen Jugend (BdAJ). However, she only discovered her Alevism at the age of 17 , so that we cannot talk in terms of her Alevi identity up until her late adolescence.

As with Jawid, it is also evident with Eylül that belonging to a religious community can already represent a stigma in the society of origin and a social identity that deviates from common standards of identity (see Goffman 1967). Unlike Jawid's case, though, Eylül's shows a strong demarcation and difference from the family of origin, which is established through denominational affiliation. Interestingly, in Eylül's case the demarcation level of the family also constitutes the demarcation from the Sunni denomination. We would therefore like to show in this empirical case study how religious plurality, belonging, and difference also permeate the inner sphere of families and do not merely encompass the coexistence of different religious and secular groups in the external sphere of society.

In particular, we focus on how Eylül's development of identity in adolescence is made possible by her being Alevi and becomes a fundamental aspect of her qualitative identity. We then wish to show how far she uses this feature of identity as a marker of difference from her primary group (family) and what potential for autonomy she has by identifying with the religious we-group acquired secondarily within the Alevi youth and the religious community.

9 Pfaff-Czarnecka notes that the concept of belonging includes the various dimensions of 'localisation' (" 'commonality', 'reciprocity' and 'connection'") and is therefore particularly useful for examining the personal 'suspended being' feeling of the individual in a group (2012, 3:26). 
We thus analyse in our empirical case the features of difference attributed to self and others in terms of the categories of generation, religion, and denomination.

This requires, first of all, some background information and historical contextualization. At the beginning of the 1990s, a number of people of Turkish origin left their country for political reasons, too - the Turkish diaspora has thus never been homogeneous but has consisted of different migration currents, such as the recruitment of guest workers and politically motivated migration. One such family to leave Turkey was Eylül's. Unlike in Jawid's case, Eylül's family probably (as far as she knows) did not face acute physical persecution because of its Alevism, but, as an Alevi-Kurdish family, was nonetheless exposed to numerous forms of discrimination. Our case study of Eylül also stands for a type of Alevi belonging: although born into an Alevi family tied to its origins, Eylül is not explicitly given this religious tradition within her family but acquires it only in the form of tacit "actional memories" (Straub 2014, 83). Such actional memories are extremely important for social interactions and communication because they can also shape the experience and actions of a person unconsciously (Straub 2014, 83; see also Noack Napoles 2019, 248). Thus, in her childhood and early adolescence, Eylül herself did not acquire any theoretical knowledge about her affiliation but rather knowledge within her family about her Alevism that was atheoretical, implicit or acquired in interaction, ambiguous, and somewhat intuitive (Zielke 2015, 164-65; Straub 2010). The fact that the family did not transmit its affiliation to Alevism can therefore be read as expressing past and present relations of collective injury between Alevis and Sunnis (see Straub and Tepeli 2021; Tepeli 2021, 2020; see also Loth and Tepeli 2019). Being Alevi is, like Jawid's Christianity in predominantly Muslim Afghanistan, a difference and negative deviation from valid standards of religious identity both in the country of origin of Turkey and within the transnational diaspora. For takiya was practised in Eylül's family, which is a "defensive strategy that aims [...] at avoiding possible persecution [...] in an unfriendly and potentially hostile environment," one that labels the Alevis as 'infidels' (Sokefeld 2008, 9). Eylül's family does not speak explicitly about this family stigma (see Goffman 1967). Her mother and one of her sisters have now become so assimilated to Sunnism that they practise what Eylül considers to be a strict interpretation of the Sunni Islam faith. Her other sister is married to an atheist and practises a religious patchwork. Her younger brother is now also a practising Sunni; only her father remains Alevi. The conflict between the two religious groups therefore also takes place at the micro-level within the inner sphere of the family.

Eylül nevertheless has a diffuse, intuitive inkling of her hushed-up family origins which oscillates back and forth between implicit knowledge and ignorance and which is intangible. This intangible and inarticulable knowledge leads Eylül to repeat the following statement in the interview: "I didn't know what I was." As she tells us: "Until three, mmh, four, five years ago I didn't even know what I was and, mmh, before that there were times when I went to the mosque because I just didn't know who or what I was." This doubt points to a biographical crisis of meaning and belonging, which she consciously addresses in the formation of her identity.

\section{Digression: Adolescence and the Relationship between Primary Family and Subject}

This formation of an autonomous identity entails complex dynamics of demarcation and identification between the subject and his or her primary group (family) as well as between subject 
and "secondary we-groups," 11 with these dynamics contributing to the further differentiation of self and other, creating new possibilities of identification, and enabling the detachment from the primary we-group, thereby fostering "a progressive differentiation of self and other" (Boesch 1996, 90). Ernst Boesch describes this from the point of view of cultural psychology as follows:

The self emerges from both identification and demarcation, and the other fulfils an important function in this process of differentiation. ... These are obviously complex processes in the formation of balances between the 'we' and the ' $I$ ', which are often resisted by the most intimate - usually unconscious - shapings of the ' $\mathrm{I}$ ' by the 'we.' (Boesch 1996, 89)

Boesch also points out that such processes of differentiation already begin within the family, in which Fritz, for example, does not want to be like his brother, or Marlies does not want to be like her mother. This is also evident in our case study.

The development of identity can therefore not be interpreted exclusively as an individual process of development but must be examined in terms of its embeddedness in intergenerational relationships (King 2007, 34). Vera King summarizes this as follows:

Developmental processes in adolescence can be described psychodynamically as a three-step process of separation, modification, and re-creation. The psychological work that must be done in each case lies firstly in saying goodbye and mourning, secondly in the ability to attack what exists and to endure the associated fears and feelings of guilt, and finally in combining the available resources from the past and present into a new life plan. (King 2007, 38)

\section{Eylül's Adolescent Identity Formation and her Search for the 'I' in the 'We'}

Eylül's particular longing and search for her religious identity in adolescence, which initially is less a deliberate and conscious search than a tentative and somewhat random groping around against the background of family experience, can easily be linked to the notion of 'crisis' in identity theory (Straub and Tepeli 2021, 172; Erikson 2015, 96). Every person has certain identity issues in his or her biography and specific resources to deal with them (King 2007, 36-37; see Keupp 2012; Gärtner and Henning 2017). Vera King writes:

It is only this kind of psychological work, which always also includes an explicit or implicit examination of one's own origins and history, that creates inner mobility, transformation, and greater freedom - whereas the negation, repression, or denial of history and the process of having become reinforce the commitment to one's own origins. (King 2007, 36-37)

Eylül does exactly that: she can overcome the adolescent crisis of identity and meaning by returning to her Alevi affiliation and religion, with religion becoming an important resource

11 By this, Boesch means "the groups to which the individual belongs outside his or her family [...] Not infrequently do they differ only partially from the 'primary group', which even approves of or supports them - the sports club, for example, for which the parents pay a contribution; and, where they deviate from the primary group, they compensate for this with new safeguards, whether of a real nature (such as friendships, pleasure, sporting success) or of an anticipated nature (such as political or religious promises of salvation)" (Boesch 1996, 90). 
for her to deal psychologically with issues to do with her origins and belonging. Like Jawid, who feels connected to his father through the freely chosen but at the same time precarious religious affiliation to Christianity, Eylül also accepts the difficult affiliation to Alevism and thereby distances herself especially from those family members who have converted and also from her Alevi father. Eylül herself explains their relationship and how she perceives the difference to her family of origin:

I can also take my parents as an example. They are not of the opinion that one should follow the path of religion, i.e., Alevism. They don't reject it one hundred percent, but they rather follow the Sunni way because that's the way they were taught in Turkey, and my parents grew up in the generation where at that very moment their parents couldn't tell their children what they were because of the fear of all that was going on back then. And today we just can't define what we are exactly and that's what we do in the organization, that's what is most important for us: the main goal is to bring our religion back to the young people. (Eylül 2017, lines 123ff.; interview with ML)

She can cope with this perceived difference to her family of origin and with the "diffusion of collective identity" ${ }^{\prime 2}$ (Tepeli 2021) within Alevism by creating a community with Alevis of the same age who deal with similar issues. The following quotation also shows how this diffusion of collective identity continues in early adolescence at the psychosocial level of the subject:

I've already told you that I always wanted to be alone and over time I realized that it had a lot to do with self-confidence and that I was a person who never walks down the street, that I could never look straight ahead. I was always bent over and looked at the ground. These are, in my opinion, signs that there is no self-confidence and that this unpleasant thing about you, the feeling of being with other people, that you don't feel like them. (Eylül 2018, lines 202ff.; interview with DT)

This excerpt from the interview shows that Eylül has both a desire and a need to belong to "like-minded people": to share similar worldviews with someone is, for her, a positive counter-horizon, while the negative counter-horizon is a community of non-like-minded people, which leads to discomfort at the emotional level. She therefore experiences and perceives difference here because she has no location in society and no community of like-minded people - she feels isolated because she cannot position herself in society. The early adolescent phase, when she was searching for identity, is framed metaphorically by the image of Eylül looking down at the ground, her eyes averted from the faces of other people, perhaps in an attempt to be invisible. She now distances herself from this Eylül because the former Eylül does not correspond to her current ideal of the self - but it is nonetheless part of her process of development.

The "turning-point" (Schütze 1981) in Eylül's biography occurred when she joined the Alevi community: through a circuitous route and following her cousins, Eylül joined her city's Alevi community at the age of 17 . She very soon felt at home in the organization and was attracted

12 We are transferring here an individual-psychological concept articulated by Erik Erikson to a collective process of finding identity that still exists in Alevism. 
by the opportunities available to its members. She herself says that she was initially enthused by the "structure," and only later by the "religion":

It fascinated me so much that these young people are standing in front, speaking and radiating this self-confidence, and there are so many topics that concern us, that shape us, that overwhelm us or guide us in any case. (Eylül 2018, line 305; interview with DT)

Eylül meets many young Alevis who become role models for her. Soon she takes on a leading role herself and, through her integration into the youth group, develops a self-efficacy that even enables her to speak in front of about 400 association members. Eylül describes her development as a "personality boom" (ibid., line 296); she has "completely outgrown herself" (ibid., line 297), which corresponds to her individual orientation towards self-development. Her positive self-image is therefore, in contrast to the less self-confident Eylül of the early years of adolescence, a person who can stand in front of 400 people and look them in the face with her head held high.

Drawing on the model developed by sociologist Fritz Schütze of the process structures in the course of life (see Schütze 1981), we can speak here of a biographical turning point that initiates a positive trajectory triggered not by her primary family but by her joining the youth association, her chosen secondary we-group. In Ernst Boesch's terms, this represents Eylül's withdrawal from her Sunni-influenced primary group, to which she feels and expresses difference. The new "balance between the 'we' and the 'I'" (Boesch 1996, 89) enables Eylül to develop new resources for action. For in the Alevi youth group, she finds resources to deal with her otherness and ignorance of her Alevi affiliation, a forum for discussing her difficult conditions of socialization and her Alevi identity with her peers. Surrounded by like-minded people, she can also make up for the lack of knowledge transmitted at home and attend seminars to acquire this knowledge cognitively and independently. She therefore gains explicit and implicit religious knowledge not through the primary socialization and transmission of rituals in the family, but through the mediation and embeddedness in the secondary we-group of peers within the community.

Thus, by returning to her original religion, one not passed down to her but rather perceived intuitively, she confidently distances herself from her parental home and her milieu of origin, where, in her view, the women have already strongly assimilated to Sunni Islam with its normatively prescribed roles. She has never (truly) felt part of this milieu and can use Alevi values to distance herself from it.

Eylül's positive biographical trajectory leads her to position herself self-confidently as what she calls a "little rebel" (Eylül 2017, line 440; interview with ML). It seems that the developmental phase of adolescence and the creation of a community with peers enabled her to form a self-achieved identity (Marcia 1980, 161) in opposition to her family of origin. The affective bonds to the Alevi youth group allows her new degrees of freedom to develop and, in socio-psychological terms, to satisfy her need for recognition and belonging.

\section{Conclusion}

Using the case study of Eylül, we have shown how a diffuse and intuitive affiliation to Alevism during childhood and adolescence led to a psychosocial crisis of belonging in adolescence. This crisis within adolescence is a productive psychological processing of issues of identity 
and belonging to do with the question, "Who am I? And who do I want to be?". Eylül addresses this question by creating her own religious identity in opposition and difference to the parental home and her parents' generation. Our research has also shown that the formation of the I-identity is closely intertwined with the subject's group identity (Erikson 2015, 17): the diffusion of collective identity within the Alevi identity has led, in the formation of Eylül's own identity, to special challenges in answering the question of who or 'what' she is. But by working with others on these questions of identity, Eylül feels a sense of belonging to other "like-minded people" among the young Alevis who share this difficulty of forming an identity and who try to solve it together. Eylül consciously chooses a religious affiliation that she inherits but that she must nevertheless work out for herself and choose as a means of creating identity and meaning. By consciously confronting and distancing herself from her family of origin, she manages to individualize herself, to classify her experiences of difference within her family, and to deal with and partly resolve the diffusion that she perceives. At a time when Eylül's mother and sister increasingly identify themselves as Sunni Muslims, Eylül finds her secondarily acquired religious we-group in being Alevi and in the group of young Alevis, and distances herself from her parents in terms of the religious and confessional difference to Sunniism.

What Jawid and Eylül share in their process of adolescent identity formation is that both consciously make religious affiliation part of their personal identity, an affiliation that represents a deviation and a stigma in their countries of origin and also in the diaspora in their own ethnic-cultural group. This can be interpreted in both cases as a sign of autonomy and mental maturity, and of the psychological processing of difference. While in Eylül's case, this results in a distancing from her family's milieu of origin, in Jawid's case it represents an intergenerational solidarity between the parents and Jawid himself. We should also mention that in Jawid's case, this deviation goes so far that as converts, his family suffered great violence in his country of origin, and that his mother is the victim of an attack that she does not survive.

Comparing the two cases is worthwhile in two respects and helps broaden our perspectives on issues to do with the peaceful or conflictual coexistence of groups within pluralistic societies. Both cases have shown how important it is for research to take into account the internal differences of migrant groups and their affiliations to milieu and religion. While Jawid, as a converted Christian, differs from the majority of Islamic society within his home country, but also in the diaspora, Eylül, as a member of an Alevi family, experiences an internal difference within the majority Sunni-Muslim religious affiliation in Turkey and the diaspora.

Our final plea is therefore that researchers of religion and migration deal not only with the diverse (multiple) affiliations of immigration groups (and this against the background of collective symbolic, psychological, but also physical, violence and harm in the country of origin (see Straub 2014)), but also with the relationship of immigration groups to the so-called majority society. Research on the life-worlds of young Alevis offers an important contribution to research on young (religious) people (see also Kaya 2009; Taşc1 2006). Since Alevism differs greatly from the main Islamic currents, the study "Young Muslims in Switzerland in search of their identity" (Baumann et al. 2017, 9) deliberately excluded young Alevis from its sample. Nevertheless, its findings provide an interesting horizon for comparison: while there are similarities in that young Alevis, like the young Muslims in the sample, also try to determine their own path in dissociating from their parents (ibid.: 38), young Alevis are certainly concerned with dissociating themselves from their parents' generation, but precisely not from their "often ritually determined and self-evident faith" (Baumann et al. 2017, 38). For 
due to the socio-cultural conditions of persecution and exclusion, and the associated strategy of dissimulation or taqiya (see above), young Alevis, unlike their Sunni peers, are often in the situation of participating in a kind of redefinition of Alevism in the context of the diaspora (see also Loth 2016, 2014).

Our case studies also show that it is worth looking into the plural microcosm of a single family or subject in order to understand the significance of religious plurality for social as well as individual action. Finally, this is also interesting because it shows how, for example, adolescents are able to combine such plurality, multiple affiliations, and difference within their own identity into a coherent unity (see Straub 2000).

\section{Acknowledgments}

This article was presented as a paper at the Final Conference of the graduate school "Regulating Religious Plurality in the Region" (RePliR) at Ruhr-Universität Bochum on October 15, 2020. The graduate school is funded by the Ministry for Culture and Sciences of the Federal State of North Rhine-Westphalia. Started in 2016, it is located both at the Center for Religious Studies (CERES) of Ruhr-Universität Bochum and at the Center for Religion and Modernity (CRM) of the University of Münster. It has funded ten graduate students with a variety of backgrounds in the humanities, theologies, and the social sciences, and will fund a new interdisciplinary cohort from 2020 to 2024. As former graduate students and associated scientists, we appreciate the wide range of possibilities for interdisciplinary research with continuous support by the principle investigators and and other persons involved.

We furthermore thank Prof. Martin Baumann (Luzern) for his astute and precise reflections on an earlier draft of this paper, which have enriched our theses and conclusions.

\section{Information on the Authors}

Natalie Powroznik is a Cultural Anthropologist (MA) with a PhD in Sociology from the University of Münster. She is working on the perceptions of, and dealings with, religion in institutional settings such as psychiatric practices, schools, and refugee hostels, as well as on religion as a category in social work. She is currently reconstructing experiences of and sociopsychological effects on adult survivors of child sexual abuse within the Catholic Church.

Martina Loth is a PhD student at the graduate school "Regulating Religious Plurality in the Region" at the University of Münster. Before that, she was assistant to the Managing Director of the German-Turkish Youth Bridge in Düsseldorf. Her educational background is a joint German-Turkish Master's Programme in Social Sciences (GeT MA) from HumboldtUniversität zu Berlin and the Middle East Technical University, Ankara. For her Bachelor's degree, she studied Comparative Studies of Culture and Religion at the University of Marburg and the Bosporus University, Istanbul.

Dilek A. Tepeli (MA Social Sciences) is writing her doctorate in the field of social and cultural psychology, and since June 2020 has been a research assistant in a DFG project led by Dr. Anna Sieben, "Cultural Spaces of Psychological Knowledge. Parent-Child Relationships from the Perspective of German and Turkish Parents," in the department of Social Theory and Social Psychology, Ruhr-Universität Bochum. Her research interests lie in the areas of identity, intergroup relationships, and habitus, as well as of social stigmatization, prejudice, and inequality. Methodologically, she is interested in the field of qualitative social research. 


\section{References}

Baumann, Martin, Jürgen Endres, Silvia Martens, and Andreas Tunger-Zanetti. 2017. "Hallo, es geht um meine Religion!" Muslimische Jugendliche in der Schweiz auf der Suche nach ihrer Identität. Forschungsbericht des Zentrums Religionsforschung. Universität Luzern.

Boesch, Ernst E. 1996. "Das Fremde und das Eigene." In Psychologie interkulturellen Handelns, edited by Alexander Thomas, 87-105. Gottingen: Hogrefe.

Brubaker, Rogers, and Frederick Cooper. 2000. "Beyond 'Identity'." Theory and Society 29: $1-47$.

Erikson, Erik. 2015. Identität und Lebenszyklus. Frankfurt a. M.

Gärtner, Christel. 2013. "Religiöse Identität und Wertbindungen von Jugendlichen in Deutschland.” Kölner Zeitschrift für Soziologie und Sozialpsychologie 65 (1): 211-33.

Gärtner, Christel, and Linda Henning. 2017. "Religion als Ressource zur Krisenbewältigung unter Bedingungen von Migration." In Religion(en) in der Einwanderungsgesellschaft. Jahrbuch für Christliche Sozialwissenschaften, edited by Marianne Heimbach-Steins, 58:91-113. Aschendorff Verlag: Münster.

Goffman, Erving. 1967. Stigma. Über die Techniken der Bewältigung der beschädigten Identität. Frankfurt am Main.

Kaya, Asiye. 2009. Mutter-Tochter-Beziehungen in der Migration. Biographische Erfahrungen im alevitischen und sunnitischen Kontext. Wiesbaden: VS Verlag für Sozialwissenschaften.

Keupp, Heiner. 2012. "Verwirklichungschancen und Identitätskapital als Bedingung und Folgen der Handlungsfähigkeit. Eine salutogenetische Perspektive." In Ressourcen im Sozialstaat und in der Sozialen Arbeit, edited by Alban Knecht and Franz-Christian Schubert, 1st Edition, 42-61. Stuttgart: Kohlhammer.

King, Vera. 2007. "Identitätssuche und Generationendynamiken in der Adoleszenz." In Identitäten im Verlauf des Lebens, edited by Jörg Wiesse, Peter Joraschky, and Dieter Bürgin, 34-51. Gottingen: Vandenhoeck \& Ruprecht.

King, Vera, and Hans-Christoph Koller, eds. 2006. Adoleszenz-Migration - Bildung. Wiesbaden: VS Verlag für Sozialwissenschaften.

Krech, Volkhard. 2008. "Religion Und Zuwanderung: Die Politische Dimension Religiöser Vielfalt." In Religiöse Vielfalt in Nordrhein-Westfalen: Empirische Befunde Und Perspektiven Der Globalisierung Vor Ort, edited by Markus Hero, Volkhard Krech, and Helmut Zander, 190-203. Paderborn: F. Schöningh.

Loth, Martina. 2014. "Wird die alevitische Jugend das Alevitentum reformieren? - Eine Generation auf der Suche nach einer Neuformulierung." In Junge Perspektiven der Türkeiforschung in Deutschland, edited by Klaus Kreiser, R. Motika, U. Steinbach, C. Joppien, and L. Schulz, 227-45. Wiesbaden: VS Verlag für Sozialwissenschaften.

. 2016. "Reform durch die Diaspora? - Jugendliche Aleviten aus Deutschland auf der 'Sivas-Gedenktour 2013'." In Junge Perspektiven der Türkeiforschung in Deutschland Vol. 2., edited by B. Doğramacı, Y. Köse, K. Öktem, and T. Völker, 179-202. Wiesbaden: VS Verlag für Sozialwissenschaften.

Loth, Martina, and Dilek A. Tepeli. 2019. “ 'Vater, woran glaubst du? - An Stock, Stein, Natur'. Ein Beitrag über Identitätsfragen junger Alevitennen und Aleviten." In Prayer, Pop and Politics. Researching Religious Youth in Migration Society, edited by Katharina Limacher, Astrid Mattes, and Christoph Novak, 249-74. Göttingen: Vandenhoeck \& Ruprecht. 
Marcia, James. 1980. "Identity in Adolescence." In Handbook of Adolescent Psychology, edited by J. Adelson, 109-37. New York: Wiley.

Noack Napoles, Juliane. 2019. "Erlebnisgründe und Verletzungsverhältnisse. Jürgen Straubs Konzeption einer psychologischen Anthropologie des vulnerablen Menschen." In Schlüsselwerke der Vulnerabilitätsforschung, edited by Robert Stöhr, Diana Lohwasser, Juliane Noack Napoles, Daniel Burghardt, Markus Dederich, Nadine Dziabel, Moritz Krebs, and Jörg Zirfas, 239-56. Wiesbaden.

Pfaff-Czarnecka, Joanna. 2012. Zugehörigkeit in der mobilen Welt: Politiken der Verortung. Das Politische als Kommunikation. Vol. 3. Göttingen: Wallstein.

Schütze, Fritz. 1981. "Prozeßstrukturen des Lebensablaufs." In Biographie in handlungswissenschaftlicher Perspektive, edited by Joachim Mattes, Arno Pfeifenberger, and Manfred Stosberg, 67-156. Sozialwissenschaftliches Forschungszentrum der Universitat Erlangen-Nürnberg.

Sokefeld, Martin. 2008. "Einleitung." In Aleviten in Deutschland. Identitätsprozesse einer Religionsgemeinschaft in der Diaspora, edited by Martin Sokefeld, 7-36. Bielefeld: transcript. Straub, Jürgen. 2000. "Identität als psychologisches Deutungskonzept." In Psychologie des Selbst, edited by Werner Greve, 279-301. Weinheim: Psychologie Verlags Union.

. 2010. "Das Verstehen Kultureller Unterschiede." In Interpretative Sozialforschung Und Kulturanalyse. Hermeneutik Und Die Komparative Analyse Kulturellen Handelns, edited by Gabriele Cappai, 39-100. Bielefeld: Transcipt.

—. 2014. "Verletzungsverhältnisse. Erlebnisgründe, unbewusste Tradierungen und Gewalt in der sozialen Praxis." Zeitschrift für Pädagogik 60 (1): 74-95.

Straub, Jürgen, and Dilek A. Tepeli. 2021. "Verletzungsverhältnisse, interreligiöse Konflikte und Abjektionen in multikulturellen Einwanderungsgesellschaften. Revisionen in der interdisziplinären Migrationsforschung." In Figurationen spätmoderner Lebensführung, edited by Susanne Benzel, Katarina Busch, Benedikt Salfeld, and Julia Schreiber, 143-95. Wiesbaden: Springer VS.

Taşc1, Hulya. 2006. Identität und Ethnizität in der Bundesrepublik Deutschland am Beispiel der zweiten Generation der Aleviten aus der Republik Türkei. Berlin: LIT-Verlag.

Tepeli, Dilek A. 2021. "Historical Hurtful Relationships and Their Psychosocial Impacts on Identity Formation of Younger Alevis in German Diaspora." In Advances in Cultural Psychology, edited by Jaan Vaalsiner, Pradeep Chakkarath, and Oswald Balandis.

. 2020. “»Egal was er auch ist, Hauptsache einer von uns«: Eine sozial- und kulturpsychologische Analyse zur Bedeutung von Moral im alevitisch-sunnitischen Verletzungsverhältnis." Journal für Psychologie 28 (2): 101-23. https://doi.org/10.30820/0 942-2285-2020-2-101.

Utler, Astrid. 2013. “Aber der Tongchun is echt komisch"-Differenzerfahrungen im Migrationskontext. Bochum: Westdeutscher Universitatsverlag.

— . 2019. "Differenz." In Stichwörter zur Kulturpsychologie, edited by Carlos Cölbl and Anna Sieben, 93-100. Gießen: Psychosozial Verlag.

Zielke, Barbara. 2015. "Attributionen kultureller Fremdheit in der Psychotherapie. Vom Kulturstandard zur kulturspezifischen Gegenübertragung." In Zur Unüberwindbarkeit kultureller Differenz: Grundlagentheoretische Reflexionen, edited by Jochen Dreher and Peter Stegmeier, 153-83. Bielefeld: Transcript. 
Zito, Dima. 2017. "Flüchtlinge als Kinder - Kinderflüchtlinge." In Flüchtlinge, edited by Cinur Ghaderi and Thomas Eppenstein, 235-56. Wiesbaden: Springer Fachmedien Wiesbaden. https://doi.org/10.1007/978-3-658-15741-8_14. 